\title{
Erratum to: Nitrogen Compounds Prevent H9c2 Myoblast Oxidative Stress-Induced Mitochondrial Dysfunction and Cell Death
}

João P. Silva • Vilma A. Sardão •

Olga P. Coutinho • Paulo J. Oliveira

Published online: 2 March 2010

(C) Springer Science+Business Media, LLC 2010

Erratum to: Cardiovasc Toxicol (2010) 10:51-65

DOI 10.1007/s12012-010-9062-2

The surname of the fourth author is misspelled in the original publication. The correct name is as follows: Paulo J. Oliveira.

The online version of the original article can be found under doi:10.1007/s12012-010-9062-2.

J. P. Silva $(\bowtie) \cdot$ O. P. Coutinho

CBMA-Molecular and Environmental Biology Centre,

Department of Biology, University of Minho, Campus de

Gualtar, 4710-057 Braga, Portugal

e-mail: jpsilva@bio.uminho.pt

V. A. Sardão · P. J. Oliveira

Center for Neurosciences and Cellular Biology,

University of Coimbra, Coimbra, Portugal

菭: Humana Press 